\title{
Increased Body Fluid Purine Levels during Hypotensive Events
}

\author{
Evidence for ATP Degradation
}

JAMES O. WOOLLISCROFT, M.D.

IRVING H. FOX, M.D.

Ann Arbor, Michigan
From the Department of Internal Medicine, Section of General Internal Medicine, and the Clinical Research Center, University of Michigan, Ann Arbor, Michigan. This work was supported in part by United States Public Health Service Grants 5M01 RR42 and 2 R01 AM 19674. Requests for reprints should be addressed to Dr. James O. Woolliscroft, 3116 Taubman Center, 1500 East Medical Center Drive, University of Michigan, Ann Arbor, Michigan 48109-0376. Manuscript submitted July 31,1985 , and accepted August 30, 1985.
Tissue ischemia leads to adenosine triphosphate (ATP) breakdown with elevation of body fluid ATP metabolites. This study tests the hypothesis that there is a direct relationship between periods of hypotension and body fluid uric acid and oxypurine levels in 19 prospectively studied patients. Significant elevations in urine oxypurine/creatinine clearance were found during periods of hypotension as compared with nonhypotensive periods $(p<0.05)$. During severe episodes of hypotension, the serum urate level was significantly elevated as well ( $p$ $<0.05$ ). The increase in these body fluid products of ATP degradation may reflect cellular ischemia during hypotensive periods. There was a weak correlation $(r=-0.31, p<0.001)$ between the systolic blood pressure and urine oxypurine/creatinine clearance. However, variability in the appearance of body fluid ATP breakdown products during episodes of hypotension suggests the interplay of multiple factors in the degradation of ATP. The use of ATP degradation products to quantitate the physiologic significance of clinical events remains tantalizing but not proved.

Hypoxia at the cellular level results in profound metabolic changes. The equilibrium between consumption and production of adenosine triphosphate (ATP), the basic energy source for cellular metabolism, is disrupted. ATP is converted to adenosine diphosphate (ADP) and adenosine monophosphate (AMP). Further metabolism to purine degradation products including adenosine, inosine, hypoxanthine, xanthine, and uric acid may occur [1] (see Figure 1). Decreased tissue ATP levels and the appearance of elevated ATP degradation products, evidence of cellular hypoxia, have been observed in models of shock [2-9], and in patients with severe cardiac failure $[10,11]$, cardiogenic shock [10], reversible cardiac arrest [12], and perinatal distress [13-21].

The extent of tissue ATP loss was directly related to the severity and duration of shock in animal models [2-6]. In human studies, there are modest correlations between elevated body fluid purine degradation products and clinical measures of antecedent hypoxia [15-17, 19], and neurologic damage at birth [20]. However, the duration and extent of the tissue hypoxia could only be inferred, making interpretation of changes in body fluid ATP breakdown products difficult.

This study was designed to prospectively test the hypothesis that there is a direct relationship between tissue hypoxia and an increase in body fluid purine levels resulting from ATP degradation. Hypotension was chosen as an indicator for tissue ischemia because it could be easily and repetitively measured clinically. The following questions were addressed: (1) Does hypotension result in elevation of levels of body fluid uric acid 
and oxypurines (hypoxanthine and xanthine)? (2) Is there consistent elevation of body fluid purine levels during hypotensive episodes? (3) Does the magnitude of changes in body fluid purine levels correlate with the extent of antecedent hypotension?

\section{PATIENTS AND METHODS}

Patients. Nineteen patients admitted to the University of Michigan medical intensive care unit during a three-month period were selected for study (Table l). Patients were included only if they were observed for at least 32 hours in the intensive care unit, were not in the postsurgical period, initially had adequate urine output, and most importantly, were clinically judged by one of us (J.O.W.) as being critically ill with a high potential for severe medical complications. All patients were followed prospectively until transferred from the medical intensive care unit or until death.

Clinical Measurements. In addition to the standard physiologic and laboratory monltoring, patlents In the study had continuous urine collections divided into three eight-hour observation periods daily. Serum urate levels and urinary uric acid and oxypurine (hypoxanthine and xanthine) excretion were measured by enzymatic spectrophotometric methods $[22,23]$. Urine creatinine was measured by an automated Jaffe reaction [24]. Serum creatinine values were measured in the Clinical Chemistry Laboratory of the University of Michigan Medical Center.

Urinary excretion of purine compounds is dependent upon renal function. To correct for variation in renal function, the ratio of urine uric acid and oxypurine excretion to creatinine clearance was calculated for each observation period. Although the patients were not in a steady state, the creatinine clearance was determined as the best approximation of renal function.

Definitions of Hypotension. For initial analysis, a hypotensive observation period was defined as an observation period with a low recorded systolic blood pressure of 90 $\mathrm{mm} \mathrm{Hg}$ or less. All observation periods with a low recorded systolic blood pressure of more than $90 \mathrm{~mm} \mathrm{Hg}$ were defined as nonhypotensive periods for this analysis. In each patient with at least one hypotensive period, the means of the serum urate, urine uric acid/creatinine clearance, and urine oxypurine/creatinine clearance from all such periods were compared with the means from all nonhypotensive periods in the same patient. The change in body fluid purine levels during hypotensive periods was calculated as a percent of control by dividing the means from the hypotensive periods by the means from the nonhypotensive periods.

The second analysis focused on discrete episodes of hypotension in individual patients. A hypotensive episode was defined as including all contiguous observation periods with a recorded low systolic blood pressure of $90 \mathrm{~mm} \mathrm{Hg}$ or less. Each such hypotensive episode was compared with all contiguous nonhypotensive observation periods (low systolic blood pressure of more than $90 \mathrm{~mm} \mathrm{Hg}$ ) immediately preceding or following the hypotensive episode. This comparison nonhypotensive group was bounded by the hypotensive episode under consideration and another hypotensive episode or the cessation or beginning of intensive care

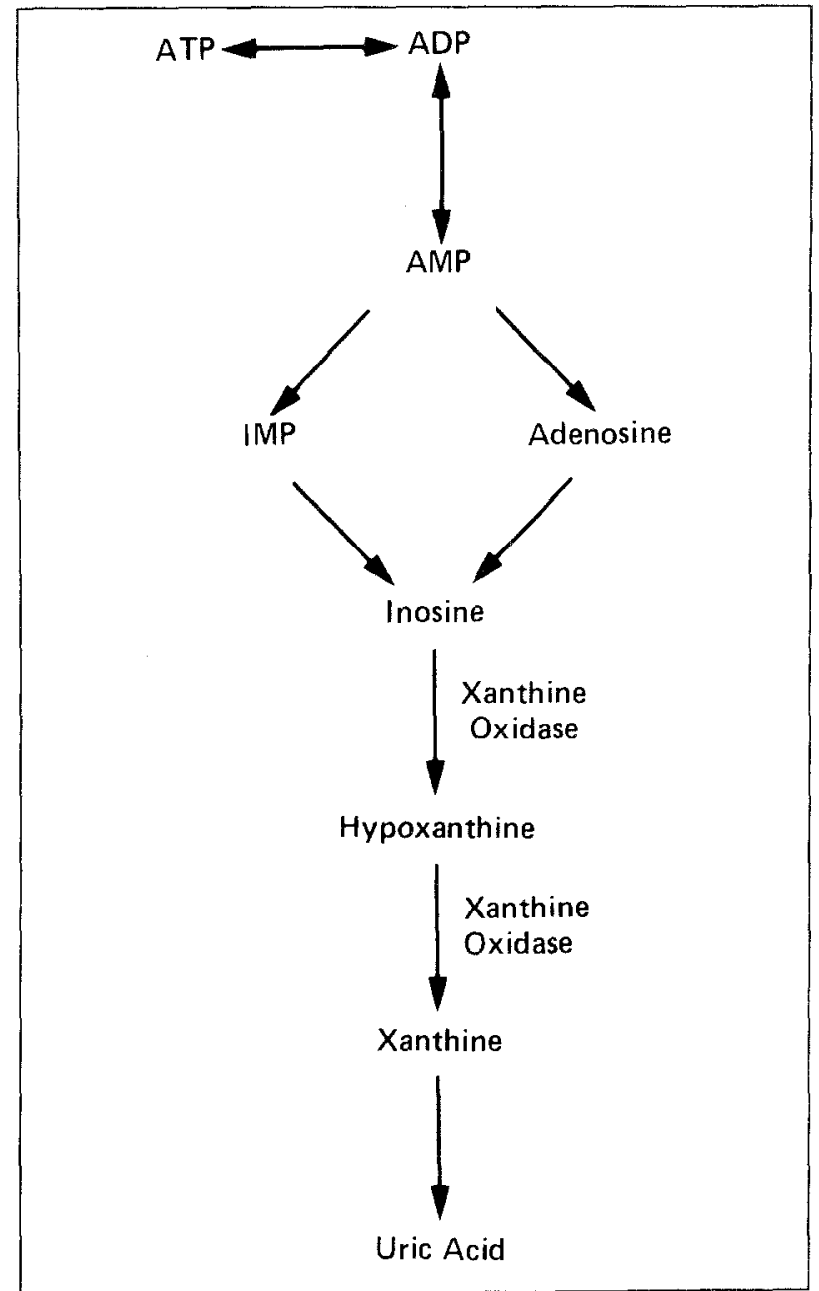

Figure 1. Purine degradation pathway.

unit monitoring. The change in serum urate, urine uric acid/creatinine clearance, and urine oxypurine/creatinine clearance was again calculated as a percent of control by dividing the means from the hypotensive episode by the means from the adjacent nonhypotensive periods.

To further restrict the analysis to the severe hypotensive episodes, observation periods with a low recorded systolic blood pressure of $90 \mathrm{~mm} \mathrm{Hg}$ or less and a mean systolic blood pressure of $105 \mathrm{~mm} \mathrm{Hg}$ or less were identified. The means from all such contiguous observation periods were compared with the means of the body fluid purine levels from all normal periods (low systolic blood pressure more than $100 \mathrm{~mm} \mathrm{Hg}$ and mean blood pressure more than 105 $\mathrm{mm} \mathrm{Hg}$ ) that were immediately adjacent-either prior to or after-the severe hypotensive episode in that person. The change in body fluid purine levels during the severe hypotensive episode was calculated as a percent of the control normal periods. The mean systolic blood pressure was determined by taking the mean of all systolic blood pressures recorded during each eight-hour observation period. The frequency of blood pressure measurement was variable depending upon the status of the patient. When patients' conditions were unstable, more frequent vital signs 


\begin{tabular}{|c|c|c|c|c|}
\hline Patient & Age and Sex & $\begin{array}{l}\text { Tolal Number of } \\
\text { Observation Periods }\end{array}$ & $\begin{array}{l}\text { Number of Observation } \\
\text { Periods with } \\
\text { Systolic Blood Pressure } \\
\text { Measurements } \leq 90 \mathrm{~mm} \mathrm{Hg}\end{array}$ & Disease \\
\hline 1 & $69 \mathrm{~F}$ & 23 & 2 & Chronic congestive heart failure, prosthetic mitral valve \\
\hline 2 & $82 \mathrm{M}$ & 16 & 0 & $\begin{array}{l}\text { Leaking abdomlnal aortic aneurysm, chronic obstructive } \\
\text { pulmonary disease }\end{array}$ \\
\hline 3 & $65 \mathrm{~F}$ & 47 & 5 & $\begin{array}{l}\text { Cardiomyopathy, congestive heart failure, chronic obstructive } \\
\text { pulmonary disease }\end{array}$ \\
\hline 4 & $16 \mathrm{~F}$ & 4 & 3 & Warm water drowning \\
\hline 5 & $24 \mathrm{~F}$ & 8 & 0 & Systemic lupus erythematosus \\
\hline 6 & $54 \mathrm{~F}$ & 6 & 0 & Infected prosthetic valve, congestive heart failure \\
\hline 7 & $47 \mathrm{~F}$ & 16 & 0 & Drug overdose \\
\hline 8 & $51 \mathrm{M}$ & 42 & 2 & Intracranial bleed, gastrointestinal bleed, pericarditis \\
\hline 9 & $64 \mathrm{~F}$ & 5 & 0 & Gastrointestinal bleed \\
\hline 10 & $67 \mathrm{M}$ & 7 & 0 & $\begin{array}{l}\text { Diabetes mellitus, hyperosmolar coma, congestive heart failure, } \\
\text { chronic renal failure }\end{array}$ \\
\hline 11 & $39 F$ & 6 & 1 & Systemic lupus erythematosus \\
\hline 12 & $71 F$ & 17 & 0 & Gastrointestinal bleed, hepatic encephalopathy \\
\hline 13 & $26 \mathrm{~F}$ & 10 & 1 & Recurrent pulmonary emboli \\
\hline 14 & $80 F$ & 40 & 2 & Paraplegia, sepsis \\
\hline 15 & $29 M$ & 12 & 0 & Budd-Chiari syndrome, hepatic failure \\
\hline 16 & $53 \mathrm{~F}$ & 55 & 8 & $\begin{array}{l}\text { Metastatic small cell carcinoma of the lung, pulmonary emboli, } \\
\text { Candida pneumonia }\end{array}$ \\
\hline 17 & $69 \mathrm{M}$ & 8 & 5 & Cirrhosis, alcohollc hepatitis, gastrointestinal bleed \\
\hline 18 & $40 \mathrm{M}$ & 93 & 25 & Alcoholic liver disease, gastrointestinal bleed, esthesioblastoma \\
\hline 19 & $63 \mathrm{M}$ & 83 & 12 & $\begin{array}{l}\text { Diabetes mellitus, coronary artery disease, refractory congestive } \\
\text { heart failure }\end{array}$ \\
\hline
\end{tabular}

were recorded. Thus, blood pressures during unstable times may be over-represented in the calculation of the mean systolic blood pressure for a given observation period.

Evidence for ATP Breakdown. Individual hypotensive episodes were classified on the basis of whether there was evidence for increased ATP breakdown or not. An episode Interpreted as reflecting Increased ATP breakdown was one that had either: (1) increased serum urate level, increased urine uric acid/creatinine clearance, and increased urine oxypurine/creatinine clearance, or (2) increased or unchanged serum urate level plus either increased urine uric acid/creatinine clearance or urine oxypurine/creatinine clearance. The comparison group for this determination were the mean values from the nonhypotensive observation periods immediately adjacent to the hypotensive episode as described previously.

Data Analysis. The student $t$ test was used to determine statistically significant changes in body fluid purine levels during hypotensive periods and episodes as compared with the appropriate nonhypotensive periods.

Subsequently, data from all observation periods in the 19 study patients were pooled. Body fluid ATP breakdown product levels during all hypotensive periods (low recorded systolic blood pressure $90 \mathrm{~mm} \mathrm{Hg}$ or less) were compared with all nonhypotensive periods (low recorded systolic blood pressure more than $90 \mathrm{~mm} \mathrm{Hg}$ ). All observation periods were treated as being independent. The Wilcoxon two-group rank sum test was used to compare the means of the serum uric acid level, urine uric acid/creatinine clearance, and urine oxypurine/creatinine clearance between the hypotensive and nonhypotensive periods.
To evaluate whether or not changes in body fluid uric acid and oxypurine levels correlated with the extent of antecedent hypotension, simple linear regression analysis was used to quantitate relationships between body fluid purine levels and the lowest systolic blood pressure recorded during each observation period. Since a wide range of normal systolic blood pressures would not be expected to result in breakdown of ATP, the regression analysis was limited to observation periods with a low systolic pressure of $100 \mathrm{~mm} \mathrm{Hg}$ or less. All statistical analyses were carried out using CLINFO with a Vax 11/730 minicomputer.

\section{RESULTS}

The 19 study patients included 12 females and seven males ranging in age from 16 to 82 years (see Table I). The mean serum urate, urine uric acid/creatinine clearance, and urine oxypurine/creatinine clearance levels for each patient during nonhypotensive (low recorded systolic blood pressure more than $90 \mathrm{~mm} \mathrm{Hg}$ ) observation periods are listed in Table II. A great deal of variability was present with mean serum urate levels ranging from 1.6 to 15.7 $\mathrm{mg} / \mathrm{dl}$, mean urine uric acid/creatinine clearance levels ranging from 1.5 to $34.7 \mathrm{mg} / \mathrm{ml}$ glomerular filtrate, and mean urine oxypurine/creatinine clearance levels ranging from 0.56 to $18.12 \mu \mathrm{mol} / \mathrm{ml}$ glomerular filtrate. A total of 498 observation periods were included ranging from four to 93 periods per patient. The group of patients who died in the intensive care unit averaged a longer stay than the other two groups and included a higher portion of the hypotensive observation periods (see Table III). 
TABLE II Mean Body Fluid Purine Levels during Nonhypotensive Observation Periods

\begin{tabular}{rrrr}
\hline Patient & $\begin{array}{c}\text { Mean } \\
\text { Serum } \\
\text { Urate } \\
\text { (mg/d) }\end{array}$ & $\begin{array}{c}\text { Mean } \\
\text { Urine Uric Acid/ } \\
\text { Creatlnine Clearance } \\
\text { (mg uric acid/ } \\
\text { ml glomerular filtrate) }\end{array}$ & $\begin{array}{c}\text { Mean } \\
\text { Urine Oxypurine/ } \\
\text { Creatinine Clearance } \\
(\mu \text { mol oxypurines/ } \\
\text { mi glomerular filtrate) }\end{array}$ \\
\hline 1 & 5.4 & 4.3 & 1.47 \\
2 & ND & 1.7 & 1.19 \\
3 & 5.0 & 4.7 & 2.19 \\
4 & 8.9 & 5.8 & ND \\
5 & 1.6 & 3.7 & 2.03 \\
6 & 3.8 & 2.8 & 1.17 \\
7 & 4.0 & 2.3 & 1.37 \\
8 & 4.7 & 3.3 & 0.99 \\
9 & 4.2 & 5.7 & 0.88 \\
10 & 15.7 & 34.7 & 18.12 \\
11 & 10.6 & 6.6 & 1.57 \\
12 & 3.7 & 3.1 & 1.56 \\
13 & 2.9 & 1.5 & 0.56 \\
14 & 4.8 & 8.7 & 3.14 \\
15 & 11.8 & 2.2 & 3.21 \\
16 & 6.5 & 4.9 & 2.26 \\
17 & 14.0 & 15.1 & 3.89 \\
18 & 2.0 & 2.7 & 1.05 \\
19 & 8.4 & 2.6 & 2.67 \\
\hline
\end{tabular}

ND $=$ not determined

Hypotensive Observation Periods in Individual Patients. Eleven patients had at least one hypotensive observation period with a low recorded systolic blood pressure of 90 $\mathrm{mm} \mathrm{Hg}$ or less. A statistically significant increase in the urine oxypurine/creatinine clearance $(p<0.05)$ was present during the hypotensive as compared with the nonhypotensive observation periods (see Table IV). No significant differences were present in the serum urate level or urine uric acid/creatinine clearance.

Hypotensive Episodes. Twenty-two separate hypotensive episodes defined by all contiguous periods with a low systolic blood pressure of $90 \mathrm{~mm} \mathrm{Hg}$ or less were recorded. This ranged from one to four such episodes per patient (see Table V). A statistically significant elevation in urine oxypurine/creatinine clearance $(p<0.05)$ was present when compared with the nonhypotensive periods. There was no significant difference in the serum urate level or urine uric acid/creatinine clearance. Figure 2 shows the elevation in urine oxypurine/creatinine clearance that occurred during an episode of hypotension in Patient 18. Hypotension was rapidly reflected in elevated excretion of these ATP breakdown products, suggesting that tissue ischemia accompanied the hypotension.

Fifty percent (11 of 22) of the hypotensive episodes from all patients met our criteria for increased ATP breakdown. There was suggestive evidence in four other episodes (Patients 3, 8, and 16, Table V), but missing data preclude such a classification. Evidence for ATP breakdown, presumably due to tissue ischemia, was usually present in hypotensive episodes associated with pulmonary problems. Unexpectedly, arrhythmias and gastroin-
TABLE III Observation Periods and Hypotensive Periods Based on Patient Group

\begin{tabular}{ccc}
\hline Group & $\begin{array}{c}\text { Mean Number of } \\
\text { Observation Periods } \\
\text { per Patient (range) }\end{array}$ & $\begin{array}{c}\text { Total Number of } \\
\text { Hypotensive Observation } \\
\text { Periods in Croup* }\end{array}$ \\
\hline $\begin{array}{c}\text { Patients who lived } \\
\text { (Patients } 1 \text { to 10) }\end{array}$ & $17.4(4-47)$ & 12 \\
$\begin{array}{l}\text { Patients discharged from } \\
\text { intensive care unit } \\
\text { who died during } \\
\text { hospitalization } \\
\text { (Patients 11 to 15) }\end{array}$ & $17.0(6-40)$ & 4 \\
$\begin{array}{l}\text { Patients who died in } \\
\text { intensive care unit } \\
\text { (Patients 16 to 19) }\end{array}$ & $59.8(8-93)$ & \\
\hline
\end{tabular}

* Hypotensive observation periods were defined as those in which a low recorded systolic blood pressure of $90 \mathrm{~mm} \mathrm{Hg}$ or less was determined.

\section{TABLE IV Changes in Body Fluid Purine Levels during All Hypotensive Periods in a Patient}

\begin{tabular}{rccccc}
\hline & $\begin{array}{c}\text { Number of } \\
\text { Hypotensive } \\
\text { Observation } \\
\text { Periods }\end{array}$ & $\begin{array}{c}\text { Total } \\
\text { Number of } \\
\text { Observation } \\
\text { Periods }\end{array}$ & $\begin{array}{c}\text { Urine } \\
\text { Serum } \\
\text { Urale* }\end{array}$ & $\begin{array}{c}\text { Urine } \\
\text { Uric Acid/ } \\
\text { Creatinine } \\
\text { Clearance* }\end{array}$ & $\begin{array}{c}\text { Oxypurine/ } \\
\text { Creatinine } \\
\text { Clearance* }\end{array}$ \\
\hline 1 & 2 & 23 & 114.2 & 43.4 & 94.4 \\
3 & 5 & 47 & 141 & 147.2 & 109.2 \\
4 & 3 & 4 & 100 & 118.1 & 457.2 \\
8 & 2 & 42 & & 82.2 & 131.5 \\
11 & 1 & 6 & 94.0 & 166.8 & 80.2 \\
13 & 1 & 10 & 103.5 & 123.4 & 361.2 \\
14 & 2 & 40 & 88.8 & 45.7 & 22.2 \\
16 & 8 & 55 & 163.0 & 231.8 & 299.8 \\
17 & 5 & 8 & 79.1 & 83.4 & 238.9 \\
18 & 25 & 93 & 237.8 & 444.5 & 423.9 \\
19 & 12 & 83 & 110.4 & 87.3 & 83.0 \\
& & & NS & NS & p < 0.05
\end{tabular}

* The change in body fluid purine levels was expressed as percent of control (Table II). This was calculated by dividing the means from all hypotensive observation periods (low systolic blood pressure $90 \mathrm{~mm} \mathrm{Hg}$ or less) by the means from all nonhypotensive observation periods (low systolic blood pressure more than 90 $\mathrm{mm} \mathrm{Hg}$ ) in the same patient.

testinal bleeding leading to hypotension frequently did not show evidence for ATP breakdown.

Severe Hypotensive Episodes. Seven patients had severe hypotensive episodes as defined by contiguous observation periods with a low systolic blood pressure of 90 $\mathrm{mm} \mathrm{Hg}$ or less and a mean systolic pressure of $105 \mathrm{~mm}$ $\mathrm{Hg}$ or less. There were 11 distinct severe episodes encompassing one to 11 hypotensive observation periods in these patients (see Table VI). Significant differences were found between the means of the serum urate level $(p$ $<0.05$ ) and urine oxypurine/creatinine clearance ( $p$ $<0.05$ ). No significant differences were present between the urine uric acid/creatinine clearance means. Eightytwo percent (nine of 11) of the severe hypotensive episodes met our criteria suggesting increased ATP break- 
TABLE V Changes in Body Fluid Purine Levels during Discrete Hypotensive Episodes in Individual Patients

\begin{tabular}{|c|c|c|c|c|c|}
\hline Patient & Serum Urate* & $\begin{array}{c}\text { Urine } \\
\text { Uric Acid/ } \\
\text { Creatinine } \\
\text { Clearance* }\end{array}$ & $\begin{array}{c}\text { Urine } \\
\text { Oxypurine/ } \\
\text { Creatinine } \\
\text { Clearance* }\end{array}$ & $\begin{array}{l}\text { Evidence of } \\
\text { Increased } \\
\text { ATP Breakdown }\end{array}$ & Associated Clinical Events \\
\hline 1 & 117.6 & 48.8 & 125.1 & + & Atrial fibrillation with rapid ventricular response \\
\hline 3 & 168.2 & 200.3 & 117.1 & + & Respiratory arrest, unresponsive after resuscitation \\
\hline 3 & 101.9 & 127.8 & 139.6 & + & Acute pulmonary edema \\
\hline 3 & ND & 89.1 & 202.4 & & Respiratory distress \\
\hline 4 & 100 & 118.1 & ND & + & Ventricular fibrillation \\
\hline 8 & ND & 69.9 & 124.7 & & Ventricular tachycardia \\
\hline 8 & ND & 88.7 & 136.9 & & Ventricular tachycardia \\
\hline 11 & 100 & 157.2 & 71.1 & + & Fever, respiratory distress, pulmonary infiltrate \\
\hline 13 & 103.5 & 123.4 & 361.1 & + & Massive pulmonary embolus \\
\hline 14 & 82.6 & 19.5 & 23.9 & & Sepsis, hypotension \\
\hline 14 & 100 & 66.0 & ND & & Gastrointestinal bleed \\
\hline 16 & 142.4 & 231.8 & 299.8 & + & Fever, seizures, disseminated intravascular coagulation \\
\hline 16 & 213.7 & ND & ND & & Unresponsive, seizures, acute renal failure \\
\hline 17 & 67.5 & 55.8 & 57.8 & & Pneumothorax during ventilatory support \\
\hline 18 & 118.3 & 83.1 & 159.2 & + & $\begin{array}{l}\text { Hypoxia secondary to aspiration requiring intubation and } \\
\text { respiratory support }\end{array}$ \\
\hline 18 & 87.0 & 48.4 & 143.7 & & Gastrointestinal bleed, coagulopathy \\
\hline 18 & 104.9 & 87.2 & 319.1 & + & Adult respiratory distreșs syndrome \\
\hline 18 & 523.5 & $1,033.8$ & 755.8 & + & Sepsis, seizures \\
\hline 19 & 109.1 & 93.5 & 116.0 & + & Acute respiratory insufficiency, arrhythmịa \\
\hline 19 & 68.3 & 86.5 & 69.9 & & Ventricular tachycardia \\
\hline 19 & 114.5 & 67.7 & 34.5 & & Ventricular arrhythmias \\
\hline 19 & $\begin{array}{l}129.2 \\
\text { NS }\end{array}$ & $\begin{array}{l}58.8 \\
\text { NS }\end{array}$ & $\begin{array}{l}40.0 \\
\mathrm{p}<0.05\end{array}$ & & Superventricular tachycardia \\
\hline
\end{tabular}

* The change in body fluid purine levels was expressed as the percent of control. This was calculated by dividing the means during hypotensive episodes (contiguous observation periods with a low recorded systolic blood pressure of $90 \mathrm{~mm} \mathrm{Hg}$ or less) by the means from adjacent nonhypotensive observation periods (periods with a systolic blood pressure of more than $90 \mathrm{~mm} \mathrm{Hg}$ ).

$\mathrm{ND}=$ not determined

down. An additional episode (Patient 16, Table VI) suggested such an increase, but did not meet our criteria due to missing data.

Pooled Data. Analysis of the pooled data from all patients included 66 hypotensive observation periods (lowest recorded systolic blood pressure $90 \mathrm{~mm} \mathrm{Hg}$ or less) and 432 nonhypotensive periods (lowest recorded systolic blood pressure more than $90 \mathrm{~mm} \mathrm{Hg}$ ). Significant increases in the means of the serum urate level $(p<0.05)$ and urine oxypurine/creatinine clearance ( $p<0.001$ ) were found. There was no statistically significant difference between the two groups for the means of the urine uric acid/creatinine clearance. There was no clear cutoff value for any body fluid purine level that would distinguish between hypotensive and nonhypotensive observation periods.

Since significant elevations were present in the urine oxypurine/creatinine clearance during periods of hypotension, further analyses addressed the third question of whether or not a correlation existed between the degree of hypotension and the level of this metabolite. Simple linear regression analysis of the low systolic blood pressure for all observation periods with a low systolic pressure of $100 \mathrm{~mm} \mathrm{Hg}$ or less with the urine oxypurine/creatinine clearance showed a correlation coefficient of $r=$ $-0.31(p<0.001)$.

\section{COMMENTS}

Eleven of the 19 study patients prospectively identified as being severely ill with a high probability of complications had hypotension by our definition. Since serial collections of urine and serum samples for ATP degradation products were made, the hypotensive observation periods could be compared with the nonhypotensive periods in the same patient or in aggregate. A persistent finding was a significant increase in the mean urine oxypurine/creatinine clearance level. These observations are in accordance with the elevated levels of urine and plasma oxypurines found in infants with perinatal distress [13,15-18,20,21].

Elevations of body fluid ATP degradation products result from cellular hypoxia. The persistent finding of elevation in the levels of oxypurines (hypoxanthine and xanthine) rather than in the serum urate or urine uric acid levels may be due to decreased accessibility of xanthine oxidase. Since uric acid is formed from hypoxanthine and xanthine by xanthine oxidase, which is most prevalent in the liver and the gastrointestinal mucosa (see Figure 1), this may reflect shunting of the blood away from the gastrointestinal tract during hypotension.

There is considerable variability in appearance of increased levels of body fluid purines depending upon the precipitating clinical event. Pulmonary problems compli- 


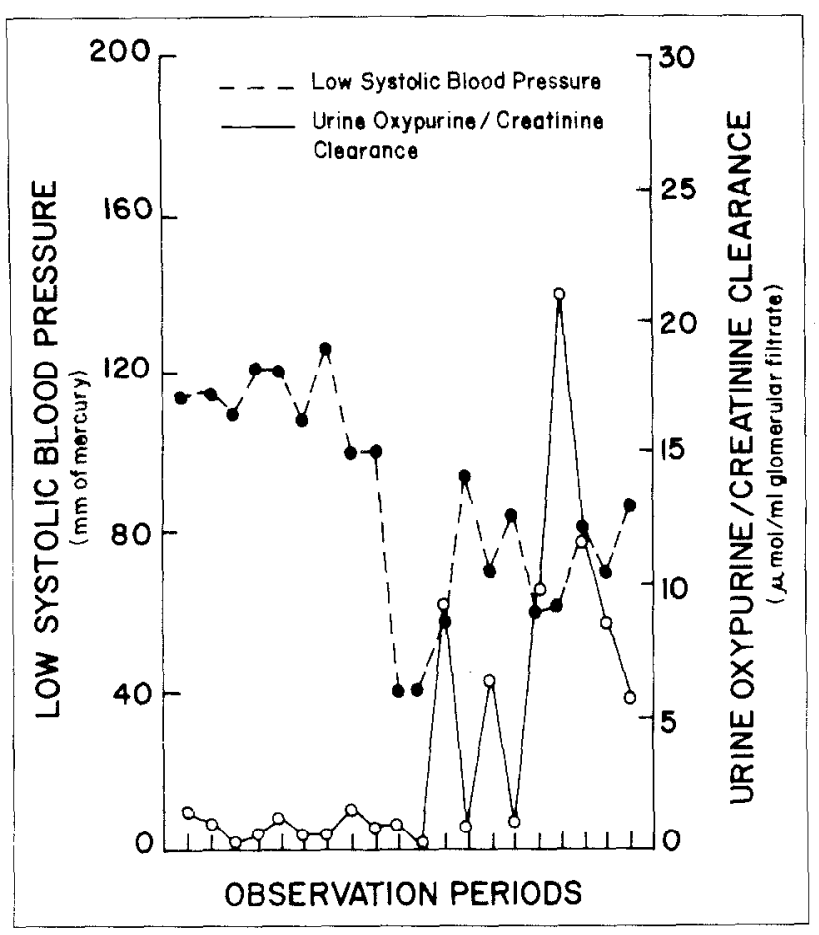

Figure 2. Effect of a hypotensive episode on urine oxypurine/creatinine clearance in Patient 18. The development of hypotension as measured by the systolic blood pressure is reflected by an increase in purine excretion. Each observation period is eight hours long.

cated by hypotension generally showed evidence for ATP breakdown. Tissue hypoxia would be very likely in such a clinical setting. Unexpectedly, cardiac arrhythmias and gastrointestinal bleeding-induced hypotensive episodes frequently did not change levels of body fluid purines. Indeed, Patients 18 and 19 , who had multiple hypotensive episodes (see Table V), showed no evidence for ATP breakdown when gastrointestinal bleeding and cardiac arrhythmias, respectively, were the underlying clinical events; however, hypotensive episodes from other causes increased their body fluid purine levels. This suggests that the physiologic consequences of hypotension are dependent upon the initiating event and additional modifying factors not defined in our study.

The inverse correlation coefficient between the systolic blood pressure and the urine oxypurine excretion implies that more severe hypotension may result in greater ATP breakdown. The low correlation coefficient indicates that blood pressure accounts for only part of the variance. There are several possible explanations for this finding. First, individual differences in uric acid metabolism may occur and were not accounted for in this calculation. Second, blood pressure is only an indirect indicator of cellular hypoxia. Third, as previously discussed, the underlying clinical events may be important determinants of the physiologic consequences of hypotension. Finally, it has been suggested that body fluid purine levels themselves may be the most accurate indicators of cellular
TABLE VI Changes in Body Fluid Purine Levels during Severe Episodes of Hypotension

\begin{tabular}{|c|c|c|c|c|}
\hline Patient & $\begin{array}{l}\text { Serum } \\
\text { Urate* }\end{array}$ & $\begin{array}{c}\text { Urine } \\
\text { Uric Acid/ } \\
\text { Creatinine } \\
\text { Clearance* }\end{array}$ & $\begin{array}{c}\text { Urine } \\
\text { Oxypurine/ } \\
\text { Creatinine } \\
\text { Clearance* }\end{array}$ & $\begin{array}{l}\text { Evidence of } \\
\text { Increased } \\
\text { ATP Breakdown }\end{array}$ \\
\hline 1 & 115.2 & 51.4 & 129.0 & + \\
\hline 3 & 232.0 & 309.8 & 358.6 & + \\
\hline 11 & 94.0 & 166.8 & 80.2 & + \\
\hline 13 & 103.5 & 166.9 & 593.1 & + \\
\hline 16 & 193.6 & ND & ND & \\
\hline 18 & 114.7 & 66.3 & 139.0 & + \\
\hline 18 & 101.4 & 70.2 & 182.4 & + \\
\hline 18 & 441.4 & 997.9 & 803.8 & + \\
\hline 19 & 109.8 & 71.8 & 114.3 & + \\
\hline 19 & 78.2 & 55.1 & 37.3 & \\
\hline \multirow[t]{2}{*}{19} & 148.4 & 58.1 & 111.1 & + \\
\hline & $p<0.05$ & NS & $p<0.05$ & \\
\hline
\end{tabular}

* The change in body fluid purine levels was expressed as the percent of control. This was calculated by dividing the means from the severe episodes of hypotension (contiguous periods with a low systolic blood pressure of $90 \mathrm{~mm} \mathrm{Hg}$ or less and a mean systolic blood pressure of $105 \mathrm{~mm} \mathrm{Hg}$ or less) by the means from adjacent normal periods (low systolic blood pressure of more than $100 \mathrm{~mm}$ $\mathrm{Hg}$ and a mean systolic pressure of more than $105 \mathrm{~mm} \mathrm{Hg}$ ). $\mathrm{ND}=$ not determined.

hypoxia. However, it is difficult to find a valid clinical measure of hypoxia to correlate with body fluid purine levels.

This study of prospectively followed patients shows that hypotension leads to elevated urine oxypurine levels. Such a rise in body fluid purine levels may be of great physiologic and clinical importance. Adenosine, which traverses the cell membrane, is a potent regional vasodilator [25]. This provides a mechanism to counteract the ischemia and attendant cellular hypoxia that precipitated the ATP breakdown. On the other hand, superoxide radicals generated by xanthine oxidase during the oxidation of ATP degradation products to uric acid may accentuate tissue damage [26]. Variability in the appearance of body fluid ATP breakdown products during episodes of hypotension indicates the interplay of complex variables. There is a need to identity and study other factors that interact to produce cellular hypoxia. The degree of body fluid purine elevation may reflect the extent of cellular hypoxia. However, at this time, it is unclear whether single determinations of a purine metabolite will give useful estimates of the severity of a clinical event beyond indicating that the purine degradation product is normal or abnormal. Therefore, the use of ATP degradation products to quantitate the physiologic significance of clinical events remains tantalizing but not proved.

\section{ACKNOWLEDGMENT}

We wish to thank Sally Jones for performing the measurements of body fluids, Steve Schmalz (Clinfo Systems Manager) for assisting in statistical methods and computer use, and Annette Schmidt for typing the manuscript. 


\section{REFERENCES}

1. Fox IH: Metabolic basis for disorders of purine nucleotide degradation. Metabolism 1981; 30: 616-634.

2. Chaudry $\mathrm{IH}$, Sayeed MM, Baue $\mathrm{AE}$ : Alterations in high-energy phosphates in hemorrhagic shock as related to tissue and organ function. Surgery 1976; 79: 666-668.

3. Chaudry $\mathrm{IH}$, Sayeed MM, Baue AE: Differences in the altered energy metabolism of hemorrhagic shock and hypoxemia. Can J Physiol Pharmacol 1976; 54: 750-756.

4. Chaudry IH, Sayeed MM, Baue AE: Effect of hemorrhagic shock on tissue adenine nucleotides in conscious rats. Can J Physiol Pharmacol 1974; 52: 131-137.

5. Ukikusa M, Kamiyama $Y$, Sato $T$, et al: Pathophysiology of hemorrhagic shock. II. Anoxic metabolism of the rat liver following acute blood loss in the rat. Circ Shock 1981; 8 : 483-490.

6. Chaudry $\mathrm{H}$, Wichterman KA, Baue AE: Effect of sepsis on tissue adenine nucleotide levels. Surgery 1979; 85: 205-211.

7. Simeone FA, Abraham J, Hopkins RW, Damewood CA: Levels of allantoin and uric acid in dogs subjected to hemorrhagic shock. J Surg Res 1975; 19: 373-380.

8. Cunningham SK, Keaveny TV: Splanchnic organ adenine nucleotides and their metabolites in haemorrhagic shock Ir J Med Sci 1977; 146: 136-143.

9. Aasen AO, Saugstad OD: Hypoxanthine in lethal canine endotoxin shock. Circ Shock 1979; 6: 277-283.

10. Karisson J, Willerson JT; Leshin SJ, Mullins CB, Mitchell JH: Skeletal muscle metabolites in patients with cardiogenic shock or severe congestive heart failure. Scand $\mathrm{J}$ Clin Lab Invest 1975; 35: 73-79.

11. Woolliscroft JO, Colfer $\mathrm{H}$, Fox $\mathrm{IH}$ : Hyperuricemia in acute illness: a poor prognostic sign. Am J Med 1982; 72: 58-62.

12. Buhl $L$, Vilhelmsen $K N$, Nielsen JR: Oxypurine release in cardiac disease. Acta Med Scand 1981; 209: 83-86.

13. Saugstad OD: Hypoxanthine as a measurement of hypoxia. Pediatr Res 1975; 9: 158-161.

14. Raivio KO: Neonatal hyperuricemia. J Pediatr 1976; 88 : 625-630.
15. Swanstrom S, Bratteby L: Hypoxanthine as a test of perinatal hypoxia as compared to lactate, base deficit, and $\mathrm{pH}$. Pediatr Res 1982; 16: 156-160.

16. Thiringer $\mathrm{K}$ : Cord plasma hypoxanthine as a measure of faetal asphyxia. Acta Paediatr Scand 1983; 72: 231-237.

17. Manzke H, Dorner K, Grunitz J: Urinary hypoxanthine, xanthine and uric acid excretion in newborn infants with perinatal complications. Acta Paediatr Scand 1977; 66: 713-717.

18. Jensen $\mathrm{MH}$, Brinklov MM, Lillquist $\mathrm{K}$ : Urinary loss of oxypurines in hypoxic premature neonates. Biol Neonate 1980; 38: $40-48$.

19. Mehes K, Horvath I, Szakolczai I: Uric acid in a single urine sample from neonates with perinatal hypoxia. Acta Paediatr Acad Sci Hung 1981; 22: 43-47.

20. Harkness RA, Whitelow AGL, Simmonds RJ: Intrapartum hypoxia: the association between neurological assess ment of damage and abnormal excretion of ATP metabolites. J Clin Pathol 1982; 35: 999-1007.

21. Harkness RA, Simmonds RJ, Coade SB, Lawrence CR: Ratio of the concentration of hypoxanthine to creatinine in urine from newborn infants: a possible indicator for the metabolic damage due to hypoxia. Br J Obstet Gynaecol 1983; 90: 447-452.

22. Liddle L, Seegmiller JE, Laster L: The enzymatic spectrophotometric method for determination of uric acid. $J$ Lab Clin Med 1959; 54: 903-913.

23. Klinenberg JR, Goldfinger S, Bradley KH, Seegmiller JE: An enzymatic spectrophotometric method for the determination of xanthine and hypoxanthine. Clin Chem 1967; 13: 834-846.

24. Technicon Auto Analyzer R method file 1969. Method N 116. Technlcon Instruments Corporation, Tarrytown, New York.

25. Berne RM: Cardiac nucleotides in hypoxia: possible role in regulation of coronary blood flow. Am J Physiol 1963; 204: 317-322.

26. McCord JM: Oxygen-derived free radicals in postischemic tissue injury. NEngl J Med 1985; 312: 159-163. 